\title{
A new source of resistance to bacterial wilt of eggplants obtained from a cross: Solanum aethiopicum L x Solanum melongena $\mathrm{L}$
}

\author{
G Ano ${ }^{*}$, Y Hebert 2, P Prior 3 , CM Messiaen 4 \\ 1 INRA CRAAG, Station d'Amélioration des Plantes, BP 1232, 97184 Pointe-à-Pitre Cedex; \\ 2 INRA, station d'Amélioration des Plantes Fourragères, 86600 Lusignan; \\ ${ }_{3}^{3}$ INRA CRAAG, Station de Pathologie Végétale et de Malherbologie, BP 1232, 97184 Pointe-à-Pitre Cedex, Guadeloupe; \\ ${ }^{4}$ INRA, Station de Biologie et de Pathologie Végétale, Place Viala, 34060 Montpellier Cedex, France
}

(Received 3 May 1990; accepted 29 April 1991)

\begin{abstract}
Summary - As the eggplant hybrid $F_{1}$ Kalenda no longer showed enough resistance to Pseudomonas solanacearum EF Smith in Guadeloupe and Martinique (French West Indies), a new breeding program was undertaken using Solanum aethiopicum as source of resistance. Despite sterility problems encountered during the first generations, selection was conducted under an artificial inoculation test according to a recurrent selection scheme including backcrosses by Solanum melongena. From the second backcross it was possible to obtain families with a high level of resistance to bacterial wilt, as well as a wide variation in the shape and colour of the fruits.
\end{abstract}

Solanum melongena / Solanum aethiopicum / Pseudomonas solanacearum / resistance / recurrent selection

Résumé - Une nouvelle source de résistance au flétrissement bactérien obtenue à partir d'un croisement entre Solanum aethiopicum $\mathrm{L}$ et Solanum melongena $\mathrm{L}$. Un nouveau programme de sélection d'aubergines utilisant Solanum aethiopicum $L$ comme source de résistance à Pseudomonas solanacearum EF Smith a été lancé en Guadeloupe et en Martinique; I'hybride $F_{1}$ Kalenda ne manifestant plus une résistance suffisante. La sélection a pu être réalisée malgré d'importants problèmes de stérilité rencontrés pendant les premières générations. Elle fut conduite généralement sous inoculation artificielle selon un modèle de sélection récurrente avec des phases de backcross par Solanum melongena $L$. Après le second backcross, il fut possible de sélectionner des familles manifestant un haut degré de résistance à la bactérie et possédant une très large variabilité pour la forme et la coloration du fruit.

Solanum melongena / Solanum aethiopicum / Pseudomonas solanacearum / résistance / sélection récurrente

\section{INTRODUCTION}

Bacterial wilt caused by Pseudomonas solanacearum EF Smith (Kelman, 1953) leads to important losses in solanaceous crops in Martinique and Guadeloupe (French West Indies, Carribean area) (Messiaen, 1975). As in other tropical and subtropical regions of the world (Buddenhagen, 1985), this disease is a limiting factor to the development of eggplant cultivation.
A breeding program conducted by Daly $(1972,1973)$ produced the line Madinina with a good level of resistance to the bacterium. Then, fruit anthracnosis, a new disease caused by Colletotrichum gloeosporioïdes $\mathrm{P}$ (Fournet, 1973) led Kaan (1973) to breed a new variety, Aranguez, which was resistant to anthracnosis. The well shaped and coloured variety was crossed with Madinina in order to produce the $F_{1}$ hybrid, Kalenda (Daly, 1986). Kalenda is highly resistant to anthracnosis and shows good tolerance to bacterial wilt.

\footnotetext{
* Correspondence and reprints
} 
In 1982, damage caused by $P$ solanacearum led to extensive losses in eggplant plantations on both islands (Messiaen, 1983). The $F_{1}$ hybrid Kalenda, still cultivated today, did not show sufficient resistance to bacterial wilt, especially in conditions such as hot season planting (JulyAugust) (Bereau and Messiaen, 1975) or planting in poorly drained fields.

Hebert (1985) showed that a high level of resistance to bacterial wilt is available in the Solanum aethiopicum Aculeatum group. This species is often described under the name $S$ integrifolium (Lester and Niakan, 1986). Beyries (1979) used it as rootstock for eggplant and tomato in naturally infected fields.

Until now, $S$ aethiopicum species as a source of bacterial wilt resistance has only been used in the cross with $S$ melongena because of infertility problems in order to obtain $F_{1}$ hybrids used as rootstock (Sakaï, 1984).

This paper reports on the first phase of the breeding program conducted at INRA (French West Indies) in order to transfer the $S$ aethiopicum Aculeatum group's resistance to $P$ solanacearum into commercial eggplant varieties.

\section{MATERIALS AND METHODS}

\section{Inoculation techniques}

Since our objective was to find a better resistance level than that of Kalenda, this variety was chosen as the susceptible control. Two techniques were used: infected field, in order to test the progenies of the crosses with the susceptible parent Aranguez; and artificial infection, to identify resistant families in the following generation.

\section{Infected field}

Trial plots were used which had received an artificial inoculation 1 or 2 years earlier. Under these conditions, the inoculum is considered to be homogeneously distributed over the plot and selecting pressure is intermediate.

\section{Artificial infection}

So that all the plants could be exposed to the same strong infectious conditions, screening for resistant plants was completed according to the method described by Prior et al (1989a). This method is based on artificial inoculation with a mixture of 3 strains (GA1, GA3, GA4) isolated from eggplant. These strains were collected from different locations in Guadeloupe and have been deposited in the Collection Nationale de Bactéries Phytopathogènes (CNBP, INRA Station de Pathologie Végétale, 49000, Angers, France). All these strains belong to Race 1 (Buddenhagen et al, 1962) and Biovar III (Hayward, 1964), but they differ in host range (Prior and Steva, 1989) and in aggressivness (Prior et al, 1990). Virulent fluidal type colonies of the bacterium were grown on tetrazolium chloride (TZC) medium (Kelman, 1954). After $48 \mathrm{~h}$ incubation at $30^{\circ} \mathrm{C}$, single colonies were cultivated for $18 \mathrm{~h}$ in liquid TZC-free medium at $30^{\circ} \mathrm{C}$, then harvested and rinsed with sterile distilled water by centrifugation $(4000 \mathrm{~g}, 20 \mathrm{~min}$ ). Final concentration of the mixed suspension was optically adjusted to $2 \times 10^{7} \mathrm{CFU} / \mathrm{ml}$. At planting time (60 days after sowing) $2 \mathrm{ml}$ of inoculum were placed close to the roots of each plant.

All the tested families were planted in a randomized complete-block design with 4 replicates (15 plants per replicate). Considering that in the case of eggplant a wilted plant dies rapidly, percentages of dead or wilted plants (WP) were observed 70 days after inoculation.

\section{Breeding for resistance to $\mathrm{P}$ solanacearum (fig 1)}

In 1982, several crosses were made between different $S$ aethiopicum entries from the INRA collection (Station d'Amélioration des Plantes Maraîchères, 84140 Montfavet, France) used as female parents and tropi-

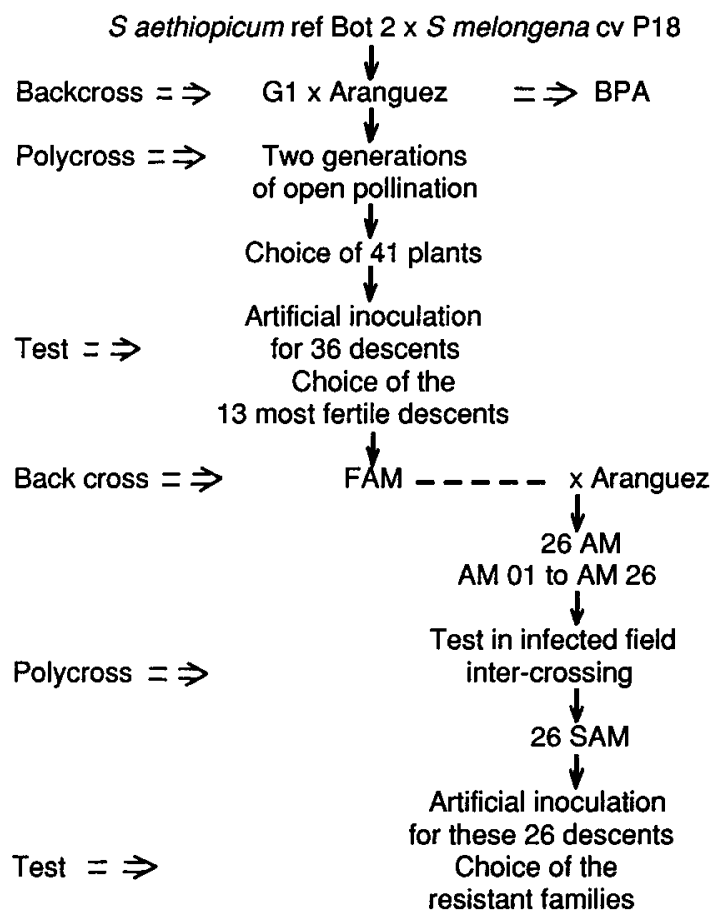

Fig 1. Pedigree of the SAM families. 
cal varieties of $S$ melongena. Embryo culture with V3 medium (Schoch and Sibi, 1978) was used in order to obtain more viable $F_{1}$ plants from these crosses. Interspecific hybrids were crossed with Aranguez. A very low fertility level was observed during this first phase of the program, and only the progenies of the cross, named BPA, - ( $S$ aethiopicum ref Bot $2 \times S$ melongena cv P18) $\times$ Aranguez - were obtained in 1983. P18, a line of Turkish origin, has a good resistance to fruit anthracnosis and bacterial wilt (Vincourt, unpublished observations) but its fruit color is not suitable because of the sun's influence on the purple shade. The progenies of the BPA cross were allowed to open-pollinate for 2 generations. At the end of 1984, this material had recovered a better though not total fertility. Non-viable combinations had been eliminated.

Later on, recurrent selection with backcrosses was performed. Selection and intercrossing were followed by a backcross phase with Aranguez in order to improve the quality of the fruit (colour, shape, size).

After the 2 generations of open pollination, equivalent to a polycross phase, fruits from 41 plants resulting from the BPA cross were harvested. In November 1984, the offsprings (named FAM families) of these 41 plants were screened by artificially inoculating plants with $P$ solanacearum. Only 36 families gave a sufficient number of plants for the test. Some flowers from resistant plants were pollinated with Aranguez. Not more than $20 \%$ of these crosses were successful, but the aging of plants (4-5 months after planting) led to an increase in fertility. Only 13 families yielded progenies, generally 5 plants per family were crossed. We thus obtained 26 progenies, named AM 01 through AM 26. They were tested for resistance to $P$ solanacearum in the infected field.

After elimination of the 2 most susceptible families (AM 02 and AM 25), the AM families were crossed in pairs at random. Twenty-six families were obtained, numbered from SAM 01 to SAM 26. They were submitted to a wilt resistance test in 1986 under artificial inoculation.

\section{Statistical analysis}

The Friedman 2-way analysis of variance by ranks was used (Friedman, 1937, 1940) because of significant variance differences within families. The "tests non paramétriques" procedure of the STATITCF micro-computer program (ITCF, 1988) was used to test the null hypothesis and to compare the families with the Kalenda control.

\section{RESULTS}

Results for the 36 FAM families are presented in table I. A wide variation between families was observed, together with a large heterogeneity within families. Out of 36 families, 20 had a resistance level which was significantly better than that of Kalenda. This $F_{1}$ hybrid, with $88 \%$ dead or wilted plants provides evidence of the efficiency and strength of the artificial inoculation.

Concerning the AM families tested in the infected field (table II), a good level of resistance was observed, since 19 families exhibited $<0 \%$ wilted plants. With $82 \%$ dead or wilted plants, Kalenda exhibits the highest susceptibility.

Table I. Ranking of FAM families issued from the first polycross for bacterial wilt resistance.

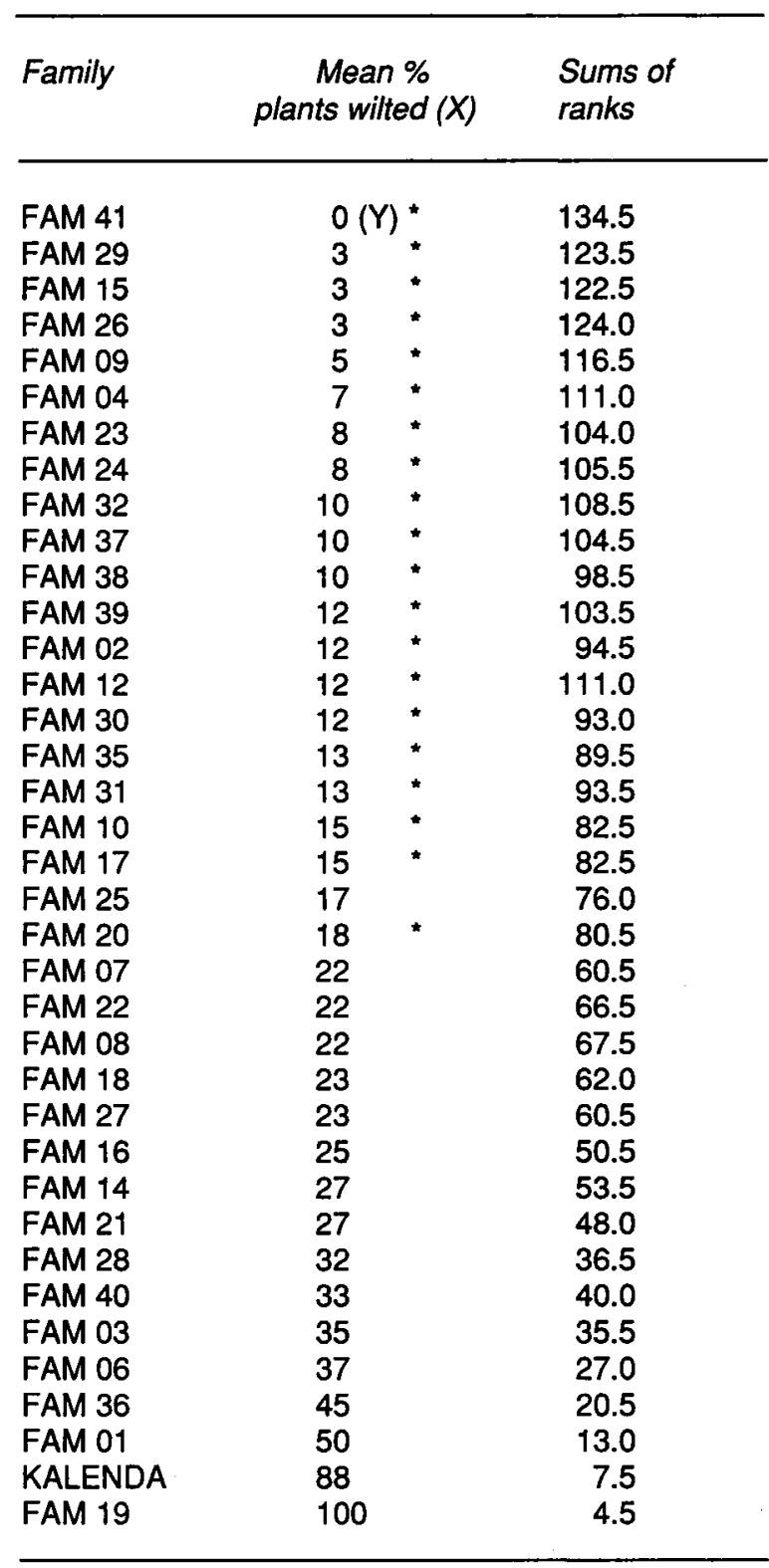

$X$ : Percentage of dead or wilted plants 70 days after inoculation calculated from 60 plants per family. $Y$ : Means within columns followed by an asterisk are significantly different from the control Kalenda at the 0.05 level of probability, according to the Friedman 2-way analysis of variance by ranks test. 
The SAM families generally showed a very good resistance to $P$ solanacearum; 15 had a resistance level significantly better than that of Kalenda (table III). All the SAM families were characterized by a good resistance to fruit anthracnosis (data not shown).

With regard to the shape and colour of the fruit, this material has a very wide variability. Fruits are long or round, and green, pink, purple or black in colour. The variability also shows up in the colour of leaves (from green to purple) and flowers (from white to purple).

Table II. Ranking of AM families issued from the second back-cross for bacterial wilt resistance.

\begin{tabular}{lll}
\hline Family & $\begin{array}{l}\text { Mean \% } \\
\text { plants wilted }(X)\end{array}$ & $\begin{array}{l}\text { Sums of } \\
\text { ranks }\end{array}$ \\
\hline
\end{tabular}

\begin{tabular}{lrll}
\hline & & & \\
AM 01 & $0(Y) *$ & 69.5 \\
AM 03 & 0 & $*$ & 69.5 \\
AM 04 & 0 & $*$ & 69.5 \\
AM 05 & 0 & $*$ & 69.5 \\
AM 06 & 0 & $*$ & 69.5 \\
AM 07 & 0 & $*$ & 69.5 \\
AM 08 & 0 & $*$ & 69.5 \\
AM 09 & 0 & $*$ & 69.5 \\
AM 10 & 0 & $*$ & 69.5 \\
AM 11 & 0 & $*$ & 69.5 \\
AM 12 & 0 & $*$ & 69.5 \\
AM 13 & 0 & $*$ & 69.5 \\
AM 15 & 0 & $*$ & 69.5 \\
AM 16 & 0 & $*$ & 69.5 \\
AM 19 & 0 & $*$ & 69.5 \\
AM 20 & 0 & $*$ & 69.5 \\
AM 21 & 0 & $*$ & 69.5 \\
AM 23 & 0 & $*$ & 69.5 \\
AM 26 & 0 & $*$ & 69.5 \\
AM 17 & 5 & & 46.0 \\
AM 22 & 5 & & 36.5 \\
AM 18 & 13 & 31.5 \\
AM 14 & 13 & & 22.5 \\
AM 24 & 18 & 30.5 \\
AM 02 & 42 & & 12.5 \\
AM 25 & 55 & & 8.0 \\
KALENDA & 82 & & 4.0 \\
& & & \\
\hline
\end{tabular}

$X$ : Percentage of dead or wilted plants under natural infestation 110 days after plantation, calculated from 60 plants per family. $Y$ : Means within columns followed by an asterisk are significantly different from the control Kalenda at the 0.05 level of probability, according to the Friedman 2-way analysis of variance by ranks test.
Table III. Ranking of SAM families, issued from the second polycross for bacterial wilt resistance.

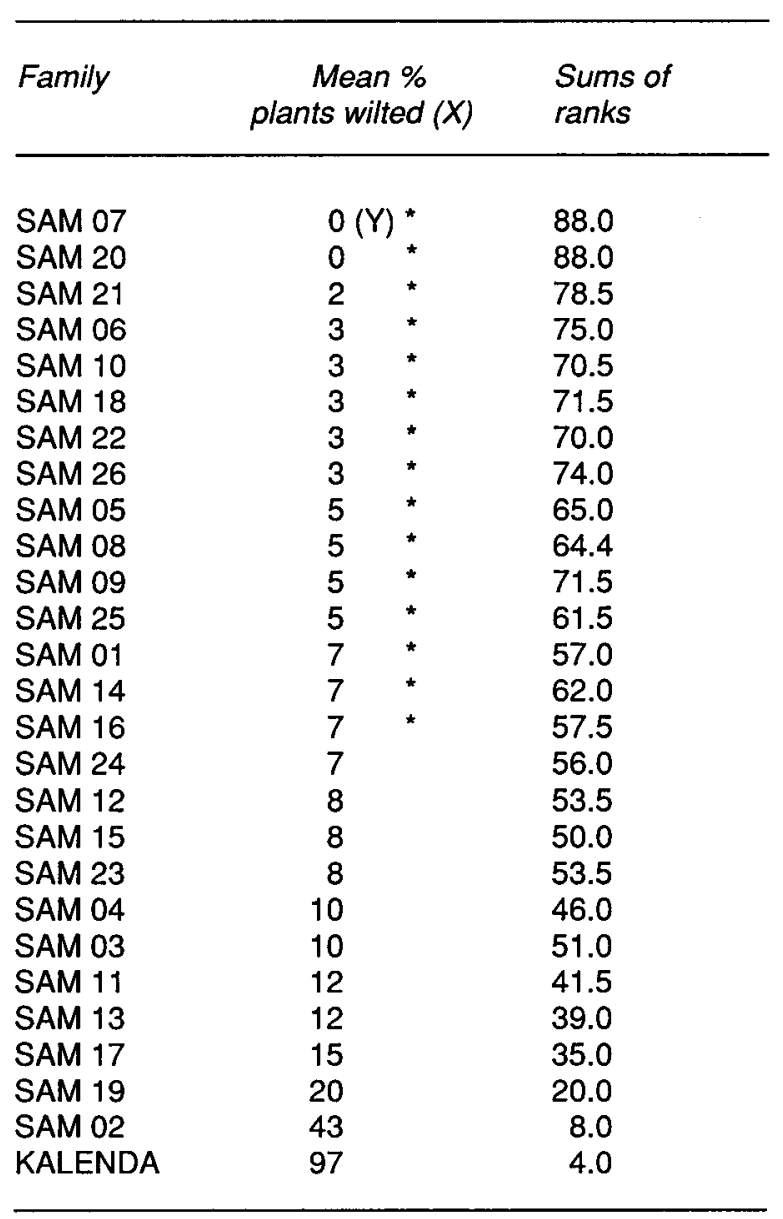

$X$ : Percentage of dead or wilted plants 70 days after inoculation calculated from 60 plants per family. $Y$ : Means within columns followed by an asterisk are significantly different from the control Kalenda at the 0.05 level of probability, according to the Friedman 2-way analysis of variance by ranks test.

\section{DISCUSSION}

The first 2 generations after the first generations issued from the interspecific hybrid were always found to be sterile. We noticed that aging of plants had a favorable effect on spontaneous fertility of interspecific hybrids under tropical conditions. Similar results such as phenotypic variation in the offspring of interspecific hybrids have frequently been observed over the course of time. 
The Aranguez parent being very susceptible to $P$ solanacearum, the results obtained indicate the average dominance of genes governing the resistance character in the selected FAM families.

It is impossible to determine the respective roles of the S aethiopicum and of the P18 parent in the genetic control of the resistance in the SAM families, the 2 original parents being resistant. The recurrent selection allowed the recombination of genes governing genetic control of bacterial wilt resistance from the 2 parents. This genetic recombination gave progenies with a significantly better resistance than that of Kalenda.

The selection method used here has proved to be very efficient in such a context where the genetic variability is wide and probably implies several partly dominant genes. The polycross phase allows the expression of various gene combinations, maintaining a large proportion of the variability induced by interspecific crosses.

A severe screening test was adopted in order to eliminate susceptible and weakly resistant plants. This test appears to be as effective as the natural infectious process, as previously stated by Schmit (1978) and to result in a better differentiation between resistant and susceptible plants, as reported by Winstead and Kelman (1952). Another advantage is that wilt symptoms were observed earlier than with natural contamination. We believe that the validity of this inoculation procedure (mixed cultures of bacterial strains) for breeding programs is increased by using representative strains of the pathogen in term of host range (race classification) and biochemical characteristics (biovar classification). This strategy is consistent with other eggplant (Goth et al, 1986; Li et al, 1988) and potato (Swanepoel and Young, 1988) breeding programs.

$P$ solanacearum strains originating from the French West Indies appear to be highly pathogenic compared with strains from other countries (Prior et al, 1989b), so that the genetic material obtained should have a resistance suitable for many countries. This resistance will be evaluated in a world - wide experimental system together with the original parents and with other sources of resistance.

The satisfactory shape and colour of the fruit of resistant genotypes makes their direct use possible after fixation by self-pollination. The most resistant families can also be used as a source of resistance to improve existing varieties, or in future breeding programs.

\section{REFERENCES}

Bereau M, Messiaen CM (1975) Réceptivité comparée des sols à une infestation par Pseudomonas solanacearum. Ann Phytopathol 7, 191-193

Beyries A (1979) Le greffage, moyen de lutte contre les parasites telluriques des solanées cultivées pour leurs fruits. Thèse Dr Univ, Univ Sci et Tech du Languedoc, F Montpellier, $166 p$

Buddenhagen IW, Sequeira L, Kelman A (1962) Designation of races in Pseudomonas solanacearum. Phytopathology 52, 726 (abstr)

Buddenhagen IW (1985) Bacterial wilt revisited. In: Proc Int Workshop PCARRD. ACIAR Los Banos (Phillip), 8-10 October 1985, 126-143

Daly P (1972) Recherches effectuées à I'IRAT - Martinique en vue de l'obtention d'une variété d'aubergine tolérante au Pseudomonas solanacearum. Agron Tropic 27, 462-472

Daly P (1973) Obtention d'une nouvelle variété d'aubergine tolérante au Pseudomonas solanacearum. Agron Trop 28, 23-27

Daly P (1986) L'implantation de l'aubergine aux Antilles ou la nécessaire adaptation du matériel végétal à des problèmes phytosanitaires. Bull Tech Inf 409/411, 453-457

Friedman $M$ (1937) The use of ranks to avoid the assumption of normality implicit in the analysis of variance. J Am Stat Assoc 32, 675-701

Friedman M (1940) A comparison of alternative tests of significance for the problem of $m$ rankings. Ann Math Stat 11, 86-92

Fournet J (1973) L'anthracnose de l'aubergine aux Antilles françaises. 1. Caractérisation et spécificité du parasite. Ann Phytopathol 5, 1-13

Goth RW, Madalageri BB, Barksdale TH, Webb RE (1986) Screening world eggplant germplasm collection for resistance to Pseudomonas solanacearum. Phytopathology 76, 563 (abstr)

Hayward AC (1964) Characteristics of Pseudomonas solanacearum. J Appl Bacteriol 27, 265-277

Hebert Y (1985) Résistance comparée de 9 espèces du genre Solanum au flétrissement bactérien (Pseudomonas solanacearum) et au nématode Meloïdogyne incognita. Intérêt pour l'amélioration de l'aubergine (Solanum melongena $L$ ) en zone tropicale humide. Agronomie 5, 27-32

ITCF (1988) STAT-ITCF Manuel d'Utilisation. Institut Technique des Céréales et des Fourrages. Paris, France, $138 p$

Kaan F (1973) Étude de l'hérédité de la résistance de l'aubergine (Solanum melongena $L$ ) à l'anthracnose des fruits (Colletotrichum gloeosporioïdes $\mathrm{f} s \mathrm{~s}$ melongenae Penzig Fournet). Ann Amélior Plantes 23, 127-131

Kelman A (1953) The bacterial wilt caused by Pseudomonas solanacearum: a literature review and bibliography. NC Agric Exp Stn Tech Bull 99, $194 p$ 
Kelman A (1954) The relationship of pathogenicity of Pseudomonas solanacearum to colony appearance in tetrazolium medium. Phytopathology 44, 693-695

Lester RN, Niakan L (1986) Origin and domestication of the scarlet eggplant, Solanum aethipicum, from $S$ anguivi in Africa. In: Solanaceae. Biology and Systematics (D'Arcy WG, ed) Columbia Univ Press, 433-455

Li HP, Goth RW, Barksdale TH (1988) Evaluation of resistance to bacterial wilt in eggplant. Plant Dis 72, 437-439

Messiaen CM (1975) Le Potager Tropical. Presses Univ France Paris, vol 1, 2

Messiaen CM (1983) Impressions de voyages en Martinique : la culture de l'aubergine va-t-elle disparaître définitivement de ce pays ? Bull Agron Antilles Guyane 1, 17-22

Prior P, Steva H (1989) Characteristics of strains of Pseudomonas solanacearum from the French West Indies. Plant Dis 74, 13-17

Prior P, Ano G, Beramis M (1989a) Stratégie de lutte contre Pseudomonas solanacearum EFS dans les sols réceptifs: un test d'inoculation au champ pour la recherche de variétés d'aubergines résistantes au flétrissement bactérien. Proc 1 er Congr Soc $\mathrm{Fr}$ Phytopathol, Rennes - Le Rheu (France), 19-20 November 1987
Prior P, Cadet P, Steva H (1989b) Variabilité du pouvoir pathogène de Pseudomonas solanacearum aux Antilles Françaises (Guadeloupe et Martinique). Acta Oecol Oecol App/ 10 (2), 132-145

Prior P, Steva H, Cadet P (1990) Aggressiveness of strains of Pseudomonas solanacearum from the French West Indies (Guadeloupe and Martinique) on tomato. Plant Dis 74, 962-965

Sakai K (1984) New summer crop cultivars (II) - new cultivars registered by the Ministry of Agriculture, Forestry and Fisheries in 1983. Eggplant Jpn $J$ Breed 34, 122-123

Schmit J (1978) Microscopic study of early stages of infection by Pseudomonas solanacearum EFS on in vitro grown tomato seedlings. In: Proc 4th Int Conf Plant Pathol Bacteriol Angers (Fra) 1978 (St Pathol Végét INRA, route de Saint-Clément, Beaucouzé, 49000, eds) 841-856

Schoch PG, Sibi M (1978) Action du rayonnement sur l'indice stomatique in situ et in vitro de feuilles de Vigna sinensis L. CR Acad Sci Paris, Sér D, 287, 1285-1287

Swanepoel AE, Young BW (1988) Characteristics of South African strains of Pseudomonas solanacearum. Plant Dis 72, 403-405

Winstead NN, Kelman A (1952) Inoculation technique for evaluating resistance to Pseudomonas solanacearum. Phytopathology 42, 628-634 